which are familiar to all zoologists. His own publica. tions are too numerous to mention in more detail, but together they constitute an integral part of the output of protozoological research in the United States during the last fifty years.

\section{Clifford Dobell}

\section{Prof. A. W. Stewart}

Emeritus Prof. Alfred Walter Stewart died at his residence in Belfast on June 30, after many years of indifferent health borne with stoical courage.

The youngest son of the late Prof. William Stewart, Dean of Faculties in the University of Glasgow, he was educated at the University of Glasgow, the University of Marburg and University College, London, and had held in turn the lectureship in organic chemistry at Belfast and the lectureship in physical chemistry and radioactivity at Glasgow. In 1919 he succeeded the late Prof. Letts as professor of chemistry at Belfast. During his tenure of office in Queen's University, Stewart did much to create the school from which many of his students went to occupy important positions in industrial and academic life at home and abroad. He was a man of great learning, gifted with a fertile imagination, and laboured continually to provide a sound and fundamental training in all branches of modern chemistry. $\mathrm{He}$ was ever ready to give counsel to those who sought his advice, and was deeply interested in the welfare of his students.

Stewart had a special interest, born from his close association with Ramsay and Collie, in the application of physical chemistry to the elucidation of the structure and properties of organic compounds, and his work upon Tesla-luminescence spectra was especially noteworthy. $\mathrm{He}$ and his co-workers developed a new field of spectroscopy by employing a fresh method of excitation to reveal series of spectra each of which is characteristic of the compound which emits it, and so added a new constitutional property to those previously known.

His love of investigation and his interest in the teaching of chemistry are revealed in his many writings, notably the volumes in his series of "Recent Advances in Physical, Inorganic and Organic Chemistry", which have reached many editions. Ho had pleasure in recalling that he had directed attention to the elements which had identical atomic weights but which differed in chemical properties and to which he gave the name 'isobars'. Since his retirement in 1944 from the chair of chemistry in the Queen's University of Belfast, which he had occupied for twenty-five years, he had devoted himself to his literary work with increased pleasure and devotion.

To have been one of Stewart's intimate friends is a privilege and a cherished memory; of a shy and retiring disposition, he avoided all forms of ostentation, and only those who had his confidence can appreciate the kindly nature, the tender affection and the stimulating effect of an evening spent with him by his fireside. Stewart's work-both as a man of science and an author-was characterized by meticulous care and thoroughness. His interests were catholic and his learning wide. British science is poorer by his loss, and another link has been severed with the pioneers of the early years of this century.

During his years of ill-health, borne with great fortitude, he had the constant companionship of his wife and only daughter, to whom sympathy is extended in their loss.

\section{Prof. G. E. M. Jauncey}

Dr. GEORGE ERIC MACDONNELI JAUNCEY, professor of physics at Washington University, St. Louis, Missouri, died on May 19 at his home in St. Louis. He was born in South Australia in 1888, and educated at the University of Adelaide; later he did graduate work under Sir William Bragg at the University of Leeds. He held instructorships in physics at Toronto, Lehigh, Missouri, and Iowa State College. In 1920 he joined the department of physics at Washington University and became professor of physics in 1930, a position which he held at the time of his death.

During the twenty years following his appointment, Jauncey carried out research on many phases of X-ray scattering, the results of which are to be found in numerous communications in the Physical Review and other journals. He was also deeply interested in students and the problems of teaching physics at all levels. Out of his interest in teaching undergraduates at an intermediate level resulted his widely used book "Modern Physics", which has passed through three editions.

A severe illness in 1940 resulted in a permanent impairment in his health, which made it impossible for him to continue experimental work. He then turned his attention to the history of physics. The papers which he had published were to have been followed by others in this field had he lived to work out his programme.

A. L. Hughes

\section{Prof. G. Matthai}

WE regret to announce the death at Cambridge on June 25 of Prof. George Matthai, formerly of the Indian Educational Service and emeritus professor of zoology in the University of the Punjab at Lahore. Dr. Matthai succeeded the late Lieut.-Colonel J. Stephenson as professor of zoology at Lahore in 1919. Under Stephenson the Lahore School of Zoology had been raised to a high degree of efficiency and was facile princeps among the Indian Schools; Prof. Matthai worked hard to maintain this proud position, though of late years Lahore has been challenged and has had to yield pride of place to Lucknow. Prof. Matthai would under normal conditions have retired in 1942 , but as a war measure his term of office was extended until 1945.

Prof. Matthai was a recognized authority on corals, and as Mackinnon Student he had worked on the coral reefs of the West Indies : he also studied the corals and reefs of the Indian and Ceylon regions. He revised the classification of the Astræidæ and published several valuable monographs, the most important of which was the British Museum Cata. logue of this family (1928). Negotiations were in progress to enable him to undertake the preparation of a similar monograph on the Fungiid Corals. His death is a great loss to systematic and taxonomic zoology.

R. B. Seymour Seweld

WE regret to announce the following deaths :

Prof. Noah Morris, regius professor of materia medica and therapeuties in the University of Glasgow since 1937.

Dr. Wilfred H. Osgood, emeritus curator of zoology in the Field Museum of Natural History, and a corresponding member of the Zoological Society of London, aged seventy-one.

Dr. John Parkinson, well known for his work in economic geology in many parts of the British Empire and elsewhere, on July 19, aged seventy-five. 